\title{
Changes in folate characteristics and its identification in broccoli (Brassica oleracea Italica) extract fermented by Lactic Acid Bacteria Mixed Culture (LAB)
}

\author{
Yati Maryati, and Agustine Susilowati \\ ${ }^{1}$ Research Center for Chemistry, Indonesian Institute of Sciences, Indonesia
}

\begin{abstract}
Broccoli (Brassica oleracea Italica) was fermented by cultures of lactic acid bacteria (LAB) as a potential source of natural folic acid. This study aimed to evalte characteristic changes and to identify folate compounds from broccoli extract, fermented by mixed LAB cultures ( $L$. bulgaricus, S. thermophulus, L.acidophilus, Bd. bifidum). The formulation of broccoli extract was fermented with variation of LAB starter culture with concentrations of 10 and $20 \%(\mathrm{v} / \mathrm{v})$, and the change of characteristic of folic acid compound during fermentation ( 0 to 48 hours) with an interval of 8 hours was evaluated. The results showed that the fermentation of broccoli extract with different concentration of LAB culture had an effect on the concentration of folic acid produced, as well as the change of concentration of folic acid during the fermentation time interval. The optimum condition was obtained based on the highest folic acid concentration of $6.74 \%$, at culture concentration of $20 \%$ during 24 hour fermentation with the value of folic acid concentration of $72.11 \mathrm{\mu g} / \mathrm{mL}, \mathrm{pH}$ value of 4.29 , total sugars of $34.61 \%$, total acids of $0,97 \%$, dissolved protein of $14.64 \mathrm{mg} / \mathrm{mL}$ and total LAB of $\log 13.02+0.05 \mathrm{cfu} / \mathrm{ml}$.
\end{abstract}

\section{Introduction}

Vegetables from the Cruciferous family such as broccoli (Brassica oleracea Italica) are foods that are often consumed and can good for health. The benefits provided from broccoli secondary plants are linked to compounds that have bioactivity; Glucosinolates and phenolic acids [1]. Broccoli contains less fat. It is low in calories and rich in vitamins, inorganic substances, and fiber [2]. Broccoli is also rich in $\beta$ carotene, ascorbic acid, selenium, quercetin, and glutathione, potentially as antioxidants. In addition, it contains high enough folic acid (folate).

Humans cannot synthesize folate, hence, it is a need for human to intake folate to prevent the deficiency of this vitamin [3]. The recommended daily intake (RDI) of folate for adults is $200-400 \mu \mathrm{g}[4,5]$. For pregnant women is recommended to be $400-600 \mu \mathrm{g}$. Although folate is always present in every food consumed by humans, folate deficiency is still common, even in developing countries [6]. Milk and fermented milk products are folate-derived foods. Folate has a very unstable nature. Therefore, to synthesize folate, culture of lactic acid bacteria in fermented milk products combined with broccoli vegetables can be used to increase folate content.

Lactic acid bacteria (LAB) include lactobacilli and bifidobacteria that are dominant in the gut and able to produce lactic acid through saccharide fermentation. LAB also acts as a live bacterial activator that can promote the growth of beneficial bacteria in the body, prevent various diseases, and regulate physiological activity by improving digestive function, inhibits cholesterol absorption, controlling immunity, enhances absorption, improves nutrient utilization and others [7,8] . It is well known that it is not only yogurt starter culture and Lactobacillus lactis which has the ability to produce folate, but other lactic acid bacteria (LAB) also possess the ability to produce folate. $L$. acidophilus is reported to be able to increase the concentration of folate in fermented milk [9]. It has also been observed that L. plantarum is capable of producing folate, even at low folate levels, when it is grown on a folate-free medium with a certain chemical composition [10]. In addition, recent research has shown that some probiotic microorganisms have the ability to synthesize folic acid such as bifidobacteria and propionibacteria. In this study we examined changes in the characteristics of folate and its identification in fermented broccoli beverages with the addition of lactic acid bacteria enriched with FOS as soluble fiber that is beneficial for the health of the body.

\section{Experimental}

\subsection{Materials}

*Corresponding author: maryati97@yahoo.com 
The ingredients used in this study were broccoli vegetable concentrate, fructooligosaccharide (FOS), skim milk, mixed cultures LAB powder (L. bulgaricus, $S$. thermophulus, L. acidophilus, Bifidum), supplied by Hansel. Co. Ltd. MRSA, MRSB, 3-aminophenol, Hydrochloric (4M), Sodium Nitrite, Sulfamic Acid were supplied by Sigma-Aldrich (St. Louis, MO). Ethanol, Folin-Ciocalteau reagent, $\mathrm{HCl}, \mathrm{KH}_{2} \mathrm{PO}_{4}$, potassium ferric cyanide, trichloroacetic acid (TCA), $\mathrm{NaOH}$, Buffer Phosphate were obtained from E-Merck.

\subsection{Fermentation process}

Cleaned broccoli vegetables were blanched for 5 minutes at $80^{\circ} \mathrm{C}$, followed by blending process of vegetable and water ratio of 1: 4 , so that broccoli vegetable porridge was obtained. The next step of filtration was done with 80 mesh filters to obtain filtrate/broccoli vegetable extract. The broccoli extract is enriched by the addition of skim milk and FOS as a source of prebiotic oligosaccharides at $9 \%$ $(\mathrm{w} / \mathrm{v})$ for each. The result of the broccoli extract formulation was sterilized at $121{ }^{\circ} \mathrm{C}$ for 15 minutes. The sterilized formulated broccoli extract was rapidly cooled to a temperature of $45^{\circ} \mathrm{C}$, and then inoculated with $10 \%$ and $20 \%(\mathrm{v} / \mathrm{v})$ of LAB starter mix culture (containing about $\left.10^{9} \mathrm{cfu} / \mathrm{mL}\right)$ obtained from $1 \%(\mathrm{w} / \mathrm{v})$ mixed LAB powder culture ( $L$ Bulgaricus, $S$. thermophulus, $L$. acidophilus, B. bifidum), inoculated against MRSB-based media and incubated at $37{ }^{\circ} \mathrm{C}$ for 24 hours. The obtained subculture was then inoculated with variations of $10 \%$ and $20 \%(\mathrm{v} / \mathrm{v})$ on the sterile formula of $15 \%(\mathrm{w} / \mathrm{v})$ of skim milk solution and $15 \%(\mathrm{w} / \mathrm{v})$ of FOS, with incubation temperature of $37^{\circ} \mathrm{C}$ for $0-48$ hours, with an interval of 8 hours.

\subsection{Cell number of $\mathrm{LAB}, \mathrm{pH}$, total sugar and Total acid (TA)}

LAB fermented broccoli extract was analyzed for bacterial growth, determined by cell number of LAB calculation from several series dilution with $0,1 \mathrm{~mL}$ sample to $10 \mathrm{ml}$ of sterile water, then using plating method with MRSA, which was done as much as 2 replicates (duplo), incubated at temperature $37^{\circ} \mathrm{C}$ for 48 hours. The number of colonies grown in the medium was calculated by multiplying the average number of colonies by dilution factor [11]. Similarly, the $\mathrm{pH}$ value measurements of the samples were measured by digital $\mathrm{pH}$ meter and total sugar measurements were made by the phenol sulfate method [12] performed at $0-48$ hours. The total acid was determined by titration of each sample with $0.1 \mathrm{M} \mathrm{NaOH}$. The result was expressed as a percentage of lactic acid, determined according to standard procedure [13].

\subsection{Analysis of folic acid}

Folic acid analysis was performed using spectrophotometric method based on the reaction of diazotizing $\mathrm{p}$ aminobenzoylglutamat acid produced after the reduction reaction of folic acid and 3-aminophenol to form a complex of yellow-orange. About $1 \mathrm{~mL}$ of standard folic acid or sample was added into $1 \mathrm{ml}$ of $4 \mathrm{M} \mathrm{HCl}, 1 \mathrm{~mL}$ of $1 \%(\mathrm{w} / \mathrm{v})$ sodium nitrite, $1 \mathrm{~mL}$ of $1 \%(\mathrm{w} / \mathrm{v})$ sulfamic acid, and $1 \mathrm{~mL}$ of $1 \%(\mathrm{w} / \mathrm{v}) 3$-aminophenol. After mixing, it formed a yellow-orange complex solution. Furthermore, the absorbance was measured using UV-VIS spectrophotometer at a wavelength of $460 \mathrm{~nm}$ [14].

\subsection{Folic acid identification by LC-MS}

After fermentation process, fermented brocoli extract were then filtered by microfiltration. Identification of folic acid and glutamate acid compounds in brocoli fermentation at the optimum condition. The obtanied permeate or purified brocoli extracts and folic acid standard. Oligomer analysis was performed by LC-MS using Mariner Biospectrometry integrated with Q-tof mass spectrometer (MS) through ESI (electrospray ionisation) system where the scan mode performed in the range of $100-1200 \mathrm{sqm}$ at $140^{\circ} \mathrm{C}$. C18 column Supelco (RP 18, 250 × $2 \mathrm{~mm}$ with a particle size of $5 \mu$ ) was used for the LC (Hitachi L 6200). Solvent was a mixture of water containing $0.3 \%$ acetic acid (A) and methanol containing $0.3 \%$ acetic acid (B) at a ratio of $80 \%$ methanol and $20 \%$ water with a flow rate of $1 \mathrm{~mL} / \mathrm{min}$. The injection volume $20 \mu \mathrm{L}$ was used in this analysis [15].

\section{Results and Discussion}

\subsection{Material Characterization}

Fresh broccoli (Brassica oleracea L.), blanching broccoli at $80{ }^{\circ} \mathrm{C}$ for 5 minutes, and blend broccoli at ratio of broccoli and water (1:4) as broccoli pulp, and broccoli extract filtered through 100 mesh sieve showed a difference in chemical compositions, as tabulated in Table 1. This difference was showed at filtrate 100 mesh (broccoli extract) containing total solids $1.54 \%$ higher compared with total solids $0.79 \%$ and in broccoli pulp. This difference also seen at total polyphenol in broccoli pulp $(0.4740 \%)$ and broccoli extract $(0.1836 \%)$ were lower compared with fresh broccoli $(0.0179 \%)$. but different from the content of folic acid in fresh broccoli, folic acid is lower than the blanching treatment.

\footnotetext{
* Corresponding author: maryati97@yahoo.co,
} 
Table 1. Composition of broccoli as substrates in LAB fermentation

\begin{tabular}{|l|c|c|c|}
\hline \multirow{2}{*}{\multicolumn{1}{c|}{ Type of broccoli }} & \multicolumn{2}{|c|}{ Composition } \\
\cline { 2 - 4 } & Total solids (\%) & Total polyphenol (\%) & Folic acid $(\boldsymbol{\mu g} / \mathbf{m L})$ \\
\hline Fresh broccoli & 25.51 & 0.0179 & 8.76 \\
\hline Blanched broccoli* & 0.5129 & 0.2704 & 32.11 \\
\hline Broccoli pulp** & 0.79 & 0.4740 & 37.72 \\
\hline Broccoli extract*** & 1.54 & 0.1836 & 33 \\
\hline
\end{tabular}

${ }^{*}$ result of blanching $80^{\circ} \mathrm{C}$ for 5 minutes

**blending at a mixture of 1 part of broccoli and 4 parts of water

***filtered via 100 mesh

Blanching process decreased possibility components contained in broccoli, besides pulverizing and filtration. Broccoli extract showed that polyphenol was trapped in other components so that not significant difference in pulp and extract. Soluble component effect on total solids, although this matter was affected by solubility properties of polyphenol in water. It had been known that both components were eased to solve in water [16].

\subsection{Cell number of LAB}

Characteristics of fermentation of broccoli extract with mixed $\mathrm{LAB}$ culture to total $\mathrm{LAB}$ count continued to increase depending on the amount of LAB culture concentration added to broccoli extract medium. The main factor influencing the increase of LAB population was the ability of lactic acid bacteria as starter culture that serves as a trigger of a metabolic process, in this case in particular is fermentation. The nature of the LAB is its ability to ferment sugars to acid and other factors that were suspected to cause an increase in LAB population was the condition of the media environment that supports optimum LAB growth. The LAB population for the $10 \%$ concentration of culture reached a maximum of $11.26 \mathrm{log}$ $\mathrm{cfu} / \mathrm{ml}$ at 48 hours fermentation time and for a culture concentration of $20 \%$ reached a maximum of $13.68 \mathrm{log}$ $\mathrm{cfu} / \mathrm{mL}$ at 40 fermentation hours, as shown in Figure 1 .

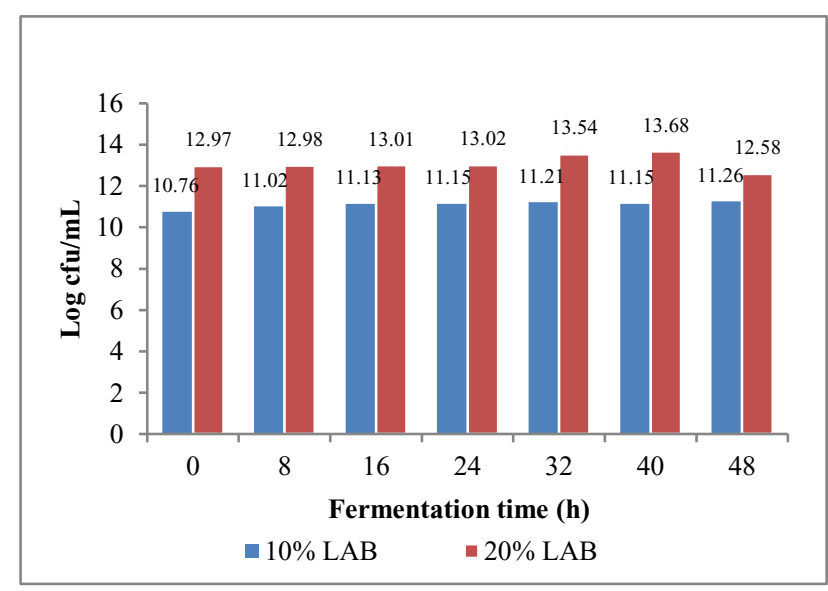

Figure 1. Changes in cell number of $\mathrm{LAB}(\mathrm{Log} \mathrm{cfu} / \mathrm{mL})$ from broccoli extract (Brassica oleracea Italica) fermented by mixed culture of Lactic acid bacteria (LAB) for 0-48 hours

\section{$3.3 \mathrm{pH}$ and Total acid (\%)}

The concentration of free hydrogen ions is reflected by the $\mathrm{pH}$ value [17]. Changes in $\mathrm{pH}$ and total acid during fermentation of broccoli extract inoculated by mixtures of lactic acid bacteria and bifidobacteria were presented in Figure 2.

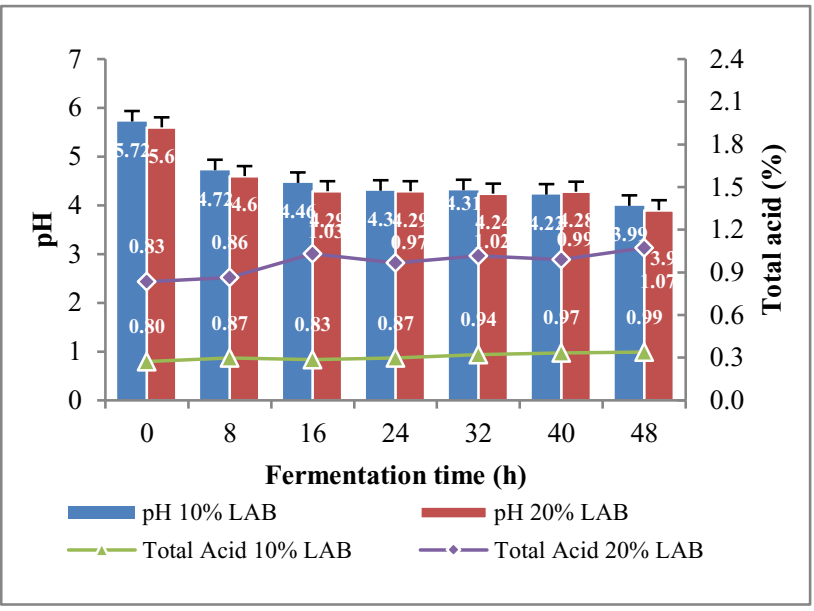

Figure 2. Relation of total acid and $\mathrm{pH}$ to characteristic changes of broccoli extract (Brassica oleracea Italica) is fermented by mixed culture of Lactic acid bacteria (LAB)

In general, broccoli extract during the fermentation time of 0 to 48 hours decreased the $\mathrm{pH}$ and increased the total acid. The concentration of lactic acid bacteria influenced the $\mathrm{pH}$ change. Low $\mathrm{pH}$ values and higher acid production were obtained from both $10 \%$ of LAB starch culture concentrations and $20 \%$ of fermented broccoli extracts.

The decrease of $\mathrm{pH}$ value after 48 hours incubation in broccoli extract was significantly different from each concentration of starter culture LAB added. In this study, the culture concentrations of $10 \%$ and $20 \%$ had a $\mathrm{pH}$ value of 5.72 and 5.60 at the beginning of fermentation ( 0 hours) and at the end of fermentation (48 hours) ranged from 3.98 and 3.90, while the total acid ranged from 0.83 and 0.80 up to $1.07 \%$ and $0.99 \%$ at the end of fermentation (48 hours). The decrease in $\mathrm{pH}$ occurred along with the production of various organic acids during the fermentation of broccoli extract by LAB. The total acid (TA) value after fermentation by LAB increased significantly depending on the concentration of LAB culture added to the broccoli extract medium. This was due 
to the measurement of TA that the measured acid component consists of dissociated and un-dissociated acids, whereas for $\mathrm{pH}$ only measures the dissociated acid component in the form of $\mathrm{H}^{+}$ions [17]. Similarly, the pattern of TA value change in treatment was consistent with the change in $\mathrm{pH}$ values (Figure 3 ). Similarly, the pattern of TA value changes in starter culture was consistent with the pattern of $\mathrm{pH}$ value changes in starter culture. Similar to $\mathrm{pH}$ values, the pattern of TA values change in general was consistent with the pattern of TA value changes in starter control.

\subsection{Total Sugar and Reducing sugar}

The change in total sugar is in line with the changes that occur in reducing sugars. The pattern of changes in total sugar and reducing sugars occurred in both culture concentration of $10 \%$ and $20 \%$ of LAB culture during fermentation 0 to 48 hours. Changes in starter culture concentration and fermentation time can be seen in Figure 3.

Changes in total sugar decrease occur at $20 \%$ concentration, this is because the greater the total content of sugar will accelerate bacterial activity in converting to acid [18]. In other words, it indicates that a single carbon source derived from prebiotics FOS (DP 2-8) in broccoli beverages is utilized by BAL for its growth, or an existing carbon source can be metabolized in $\beta(2-1)$ fructans with a DP Higher than 2 (two). The total sugar increased during the fermentation process $(0-48 \mathrm{~h})$ at the culture concentration of $10 \%$ to $20 \%$, the increase of total sugar and reducing sugar showed that too large $\mathrm{BAL}$ concentration resulted in inefficient culture in metabolizing FOS compounds in the time range until 48 hours at concentrations of $10 \%$ and 32 hours at a concentration of $20 \%$ of LAB cultures, this may be influenced by physical and chemical factors from the tested sample.

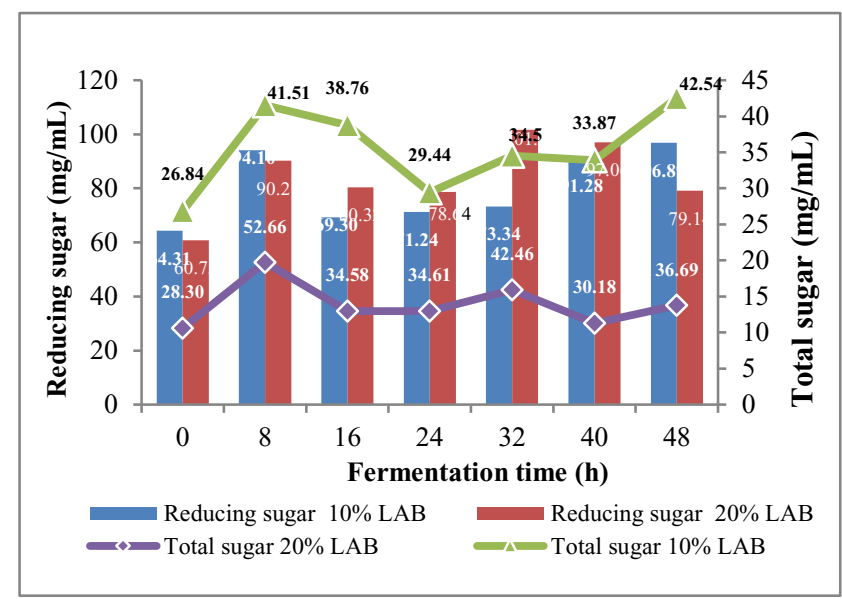

Figure 3. Relationship of total sugar and sugar reduction to the characteristic changes of broccoli extract (Brassica oleracea italica) fermented by mixed cultures Lactic acid bacteria (LAB)

\subsection{Folic acid and Dissolved protein}

The tendency of yield on the rate of fermentation to folic acid, the data showed during the fermentation time of broccoli extract gave the result of folic acid fluctuated, the data obtained was significantly different during the fermentation time.

Folic acid at optimum condition was obtained at initial fermentation ( 32 hours) at 10\% LAB culture concentration while at optimum $20 \%$ culture concentration at 24 hours fermentation time, the concentration of folic acid in each starter culture was 71.20 and $72.11 \mu \mathrm{g} / \mathrm{mL}$. Folic acid is a compound that is very sensitive to light, oxygen and temperature, therefore fermentation by using lactic acid bacteria culture can improve the recovery of natural folic acid because it is done under anaerobic conditions to minimize interaction with light and oxygen. In addition, microbial activity in the culture of lactic acid bacteria is expected to help the stability of natural folic acid during fermentation. The fermentation time will increase the chemical composition change from the fermentation of broccoli extract. Changes in dissolved protein levels during the fermentation time occur because of the role of the enzyme produced by the BAL during the fermentation process takes place. Protease is an enzyme capable of hydrolyzing peptide bonds in proteins. Lactic acid bacteria have the ability to produce proteolytic enzymes around cell walls, cytoplasmic membranes, or in cells [19]. Increased levels of dissolved protein in fermented broccoli extract may also occur due to increased growth and proliferation of BAL cells (L. acidophilus, Bd. bifidum, L. bulgaricus and $S$. thermophilus). This is due to the protein in the extract of broccoli undergoing hydrolysis process by proteolic enzyme produced by BAL during fermentation. Rahman [20] states that lactic acid-forming bacteria in fermentation produce proteolic enzymes that help protein degradation.

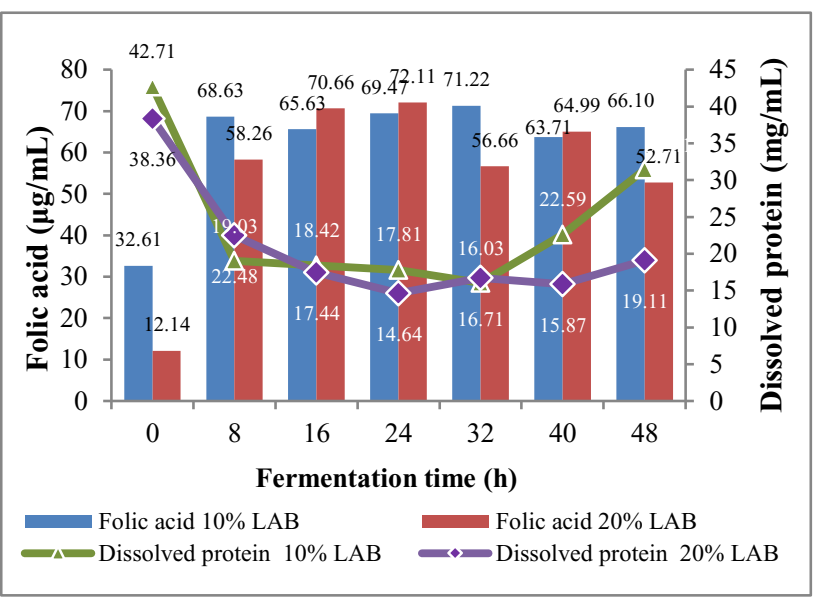

Figure 4. The relation of soluble protein and folic acid to changes in the characteristics of broccoli extract (Brassica oleracea italica) fermented by mixed cultures Lactic acid bacteria (LAB).

Folic acid at optimum condition was obtained at initial fermentation ( 32 hours) at 10\% LAB culture concentration while at optimum $20 \%$ culture concentration at 24 hours fermentation time, the concentration of folic acid in each 
starter culture was 71.20 and $72.11 \mu \mathrm{g} / \mathrm{mL}$. Folic acid is a compound that is very sensitive to light, oxygen and temperature, therefore fermentation by using lactic acid bacteria culture can improve the recovery of natural folic acid because it is done under anaerobic conditions to minimize interaction with light and oxygen. In addition, microbial activity in the culture of lactic acid bacteria is expected to help the stability of natural folic acid during fermentation. The fermentation time will increase the chemical composition change from the fermentation of broccoli extract. Changes in dissolved protein levels during the fermentation time occur because of the role of the enzyme produced by the BAL during the fermentation process takes place. Protease is an enzyme capable of hydrolyzing peptide bonds in proteins. Lactic acid bacteria have the ability to produce proteolytic enzymes around cell walls, cytoplasmic membranes, or in cells [19]. Increased levels of dissolved protein in fermented broccoli extract may also occur due to increased growth and proliferation

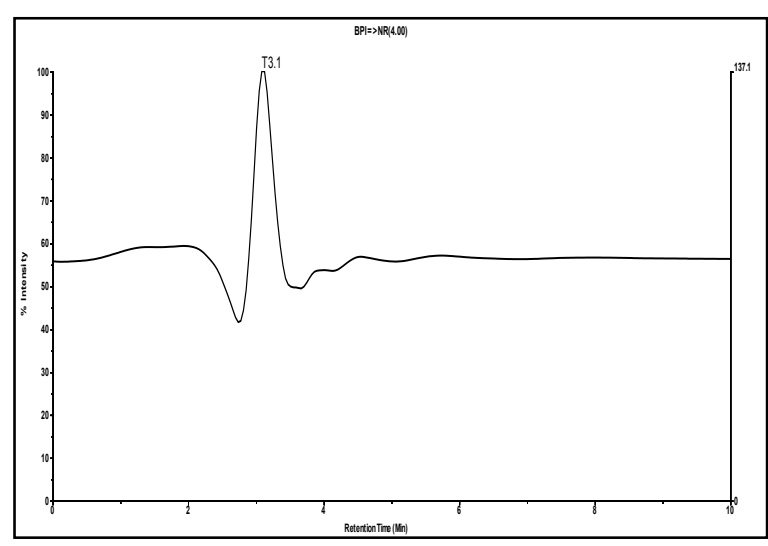

(a)

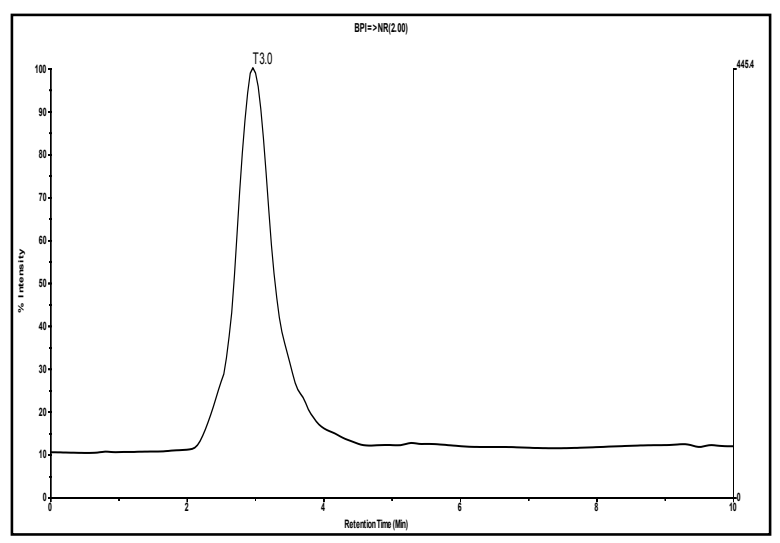

(c) of BAL cells (L. acidophilus, Bd. bifidum, L. bulgaricus and $S$. thermophilus). This is due to the protein in the extract of broccoli undergoing hydrolysis process by proteolic enzyme produced by BAL during fermentation. Rahman [20] states that lactic acid-forming bacteria in fermentation produce proteolic enzymes that help protein degradation.

\subsection{Identification of folic acid with LCMS}

Broccoli extract contains high enough folic acid and can be seen the changes during the fermentation process with the addition of lactic acid bacteria. Folic acid is a heterocyclic compound with a conjugated pentoric acid structure with one or more L-glutamates linked via an amino acid-carbonyl group. Folic acid has one L-glutamic residue with the name "pteroilglutamic acid". Folic acid can be reduced to $\mathrm{H} 2$ folate or tetrahydrofolate ( $\mathrm{H} 4$ folate) which is an active form of coenzyme vitamin [21].

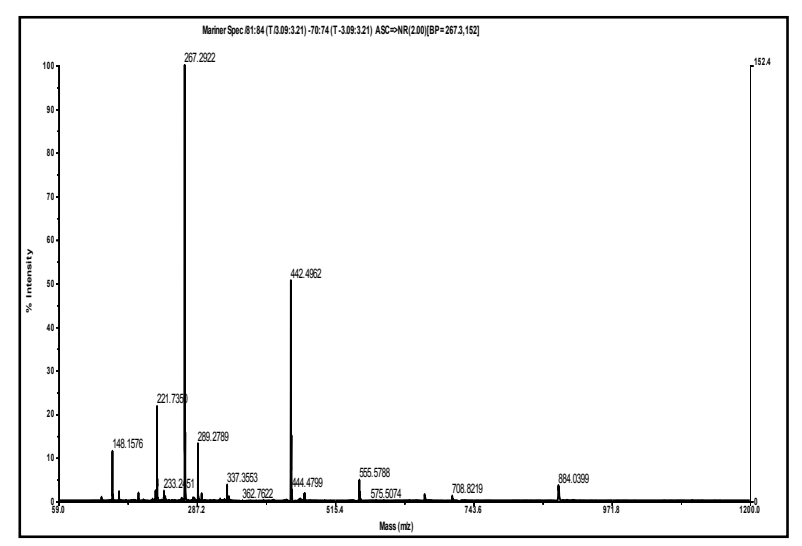

(b)

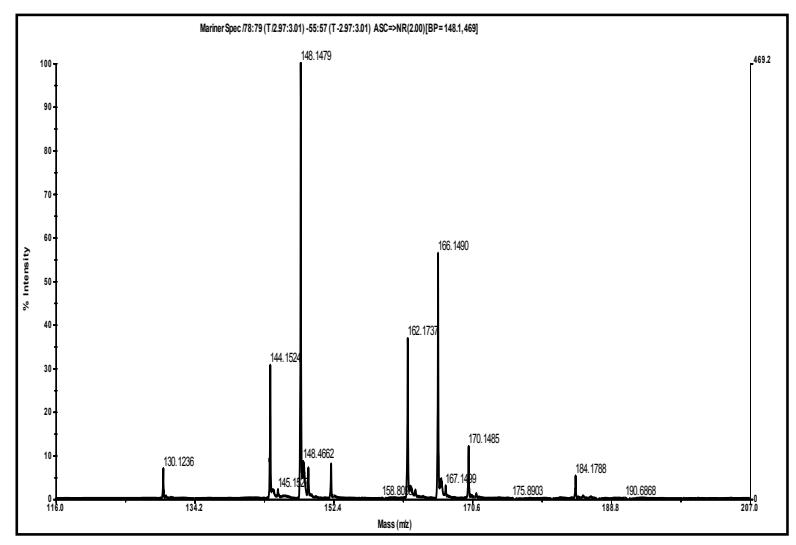

(d)

Figure 5. Standard solution of glutamate (c) and mass spectra from T 3.0 from chromatogram folic acid standard (b), Standard solution of glutamate (c) and mass spectra from T 3.0 from chromatogram glutam e standard (d)

Figures $5 \mathrm{a}$ and $5 \mathrm{~b}$ show that the standard of folic acid is dominated by compounds with BM 442,5, 443,16, 443,51 and 444,48 Da, respectively. With the successive intensities of $50.55,8.35,15$ and $2.44 \%$ in other words folic acid is possible on the BM. In Figs. 5c and 5d show that the standard of glutamic acid is dominated by compounds with BM 148.15, 148.47 and 149.14 Da respectively. With successive intensities of 100, 8.51 and $7 \%$ in other words glutamic acid is possible on the BM. The results of mass spectra of broccoli extract fermentation by mixed LAB cultures were obtained, at a culture concentration of $20 \%$ during 24 -hour fermentation 
(Fig. 6) than the standard mass spectra of folic acid and glutamate (Figs. 5a and 5c), identified eight compounds at T 3.7 where 2 (two) compounds are identical as folic acid

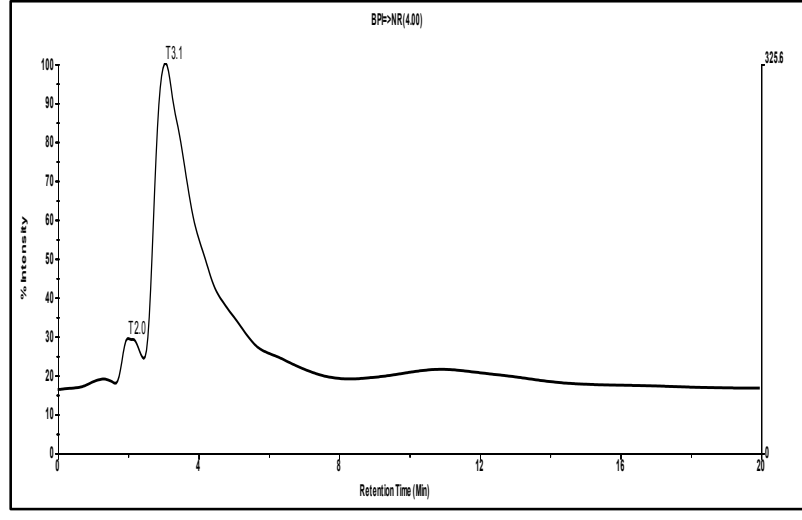

(a) with molecular weight 441.23 , and 443.29 , with the relative intensity respectively of $3.48 \%$ and $2.11 \%$.

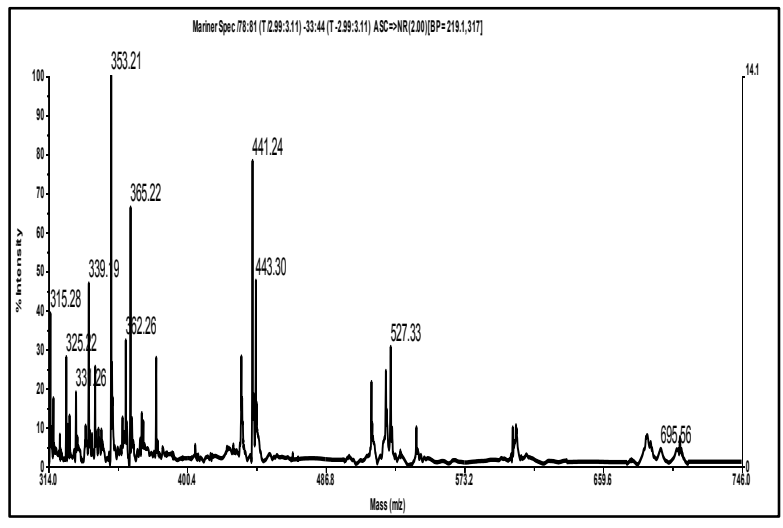

(b)

Figure 6. Chromatogram of fermented broccoli (a) and mass spectra of T3.07 from chromatogram of fermented broccoli and optimum process conditions based on highest folic acid in a culture concentration of $20 \%$ during fermentation time of $24 \mathrm{~h}$ (b)

While the identical compound as glutamic acid is obtained 5 (five) compounds with molecular weight of $145.08,159.046,163.09,175.10$, and 191.08, with relative intensity of $0.86 \%, 12.15 \%, 1.58 \%, 2.95 \%$, and $28 \%$ of 43 compounds respectively. The presence of folic acid in the fermentation of broccoli extract is presented in Table 2.

Table 2. Identification of folic acid and degraded folic acid compounds in fermented extract broccoli using lactic acid bacteria (LAB) mix culture by LC-MS

\begin{tabular}{|c|c|c|c|l|}
\hline No. & Centroid Mass & $\begin{array}{c}\text { Relative } \\
\text { Intensity (\%) }\end{array}$ & Area & \multicolumn{1}{c|}{ Represented Compounds } \\
\hline 1. & 145.156904 & 0.86 & 26.85 & 2-aminopentanedioateglutamate $\mathrm{C}_{5} \mathrm{H}_{7} \mathrm{NO}_{4}{ }^{-2}$ \\
\hline 2. & 159.060508 & 12.15 & 265.59 & Lithium L-glutamate C5H8NNaO4 \\
\hline 3. & 163.167017 & 1.58 & 30.97 & 2-amino-4-hydroxypteridine \\
\hline 4. & 175.183459 & 2.95 & 59.96 & L-Glutamic acid 5-ethyl ester C7H13NO4 \\
\hline 5. & 191.118699 & 28 & 653.26 & L-Glutamic acid disodium salt C5H7NNa2O4 \\
\hline 6. & 192.073319 & 1.2 & 24.69 & Pterin-carboxylic acid C7H5N5O3 \\
\hline 7. & 441.397255 & 3.48 & 101.33 & Isofolic Acid C19H19N7O6 \\
\hline 8. & 443.417706 & 2.11 & 40.96 & (6S)-5,6,7,8-tetrahydrofolate dianion $\mathrm{C} 19 \mathrm{H} 21 \mathrm{~N} 7 \mathrm{O} 6-2$ \\
\hline
\end{tabular}

\section{Conclusion}

Characteristics changes of the bioactive component of fermented broccoli extract mixed of starter cultures of LAB (L. bulgaricus, S. thermophilus, L. acidophilus, Bd. bifidum) with different concentrations of LAB cultures and different time of fermentation affect to folic acid, dissolved protein, total sugar, total acids, and total BAL. The optimum conditions obtained by the highest concentration folic acid at a concentration of $20 \%$ during the fermentation time of $24 \mathrm{~h}$ with a value of folic acid concentration of $72.11 \mu \mathrm{g} / \mathrm{mL}, \mathrm{pH}$ value of 4.29 , total sugars of $34.61 \%$, total acids of $0,97 \%$, dissolved protein of $14.64 \mathrm{mg} / \mathrm{mL}$ and total LAB of $\log 13.02+0.05 \mathrm{cfu} /$ $\mathrm{ml}$. Identification of glutamate and folic acid through LCMS showed identified eight compounds at $\mathrm{T}$ 3.7. Where 2 (two) compounds are identical as folic acid and as glutamic acid is obtained 5 (five) compounds.
The authors thank Puspa Dewi Lotulung for assistance assistance in the use of the LC MS at the NPPC (Natural Products and Pharmachemical Chemistry, Research Center for Chemistry).

\section{References}

1. Rebecca J. Robbins, Anna-Sigrid Keck, Gary Banuelos, and John W. Finley. (2005), Cultivation conditions and selenium fertilization alter the phenolic profile, glucosinolate, and sulforaphane content of broccoli. Journal of Medicinal Food. July 2005, 8(2): 204-214.

2. Fahey J. W., Zhang Y, \& Talalay, P. (1997). Broccoli sprouts: an exceptionally rich source of inducers of enzymes that protect against chemical carcinogens. Proc Natl Acad Sci 94, 10367-72.

3. LeBlanc J. G., de Giori G. S., Smid E. J., Savoy G., Hugenholtz J., \& Fernando Sesma. (2007). Folate production by lactic acid bacteria and other food- 
grade microorganisms, Communicating Current Research and Educational Topics and Trends in Applied Microbiology A. Méndez-Vilas (Ed.).

4. Institute of Medicine. (1998). Dietary Reference Intakes for Thiamin, Riboflavin, Niacin, Vitamin B6, Folate, Vitamin B12, Panthothenic Acid, Biotin, and Choline, National Acad Pr; Washington, DC.

5. FAO/WHO. (2002). in: Human vitamin and mineral requirements, Bangkok, Thailand

6. Konings E. J., H. H. Roomans, E. Dorant, R. A. Goldbohm, W. H. Saris and P. A. van den Brandt. (2001). Folate intake of the Dutch population according to newly established liquid chromatography data for foods, Am J Clin Nutr 73. 4. 765

7. Kim M. J., \& Kim G. R. (2006). In vitro evaluation of cholesterol reduction by lactic acid bacteria extracted from Kimchi. Korean J Culinary Res 12, 259-68.

8. Gao M. T., Kaneko M., Hirata M., Toorisaka E., and Hano T. (2008). Utilization of rice bran as nutrient source for fermentative. Bioresour Technol 99,3659-64

9. Lin, M. Y., and C. M. Young. (2000). Folate levels in cultures of lactic acid bacteria. Int. Dairy J. 10:409-414

10. Sybesma W. , Starrenburg, M., Tijsseling, L., Hoefnagel M. H. \& Hugenholtz J. (2003). Effects of Cultivation Conditions on Folate Production by Lactic Acid Bacteria, Appl Environ Microbiol 69. 8. 4542

11. [BAM]. Bacteriological Analitical Manual. 2001. Aerobic plate count [Internet]. Retrieved from http://www.fda.gov/Food/FoodScienceResearch/La boratory/Methods/ucm 063346. htm

12. Dubois, M., Gilles K. A., Hamilton J. K., Rebers, P., Smith, F. (1956). Colorimetric method for determination of sugars and related substances, Anal. Chem. 28 (3); 350-356.

13. AOAC. 1984. Official Methods of Analysis 14th edn. Washington, DC, Association of Official Analytical Chemists.

14. Ruengsitagoon, W. \& Hattanat, N. (2012). Simple spectrophotometric method for determination of folic acid, The 4th Annual Northeast Pharmacy Research Conference, Thailand.

15. Eichhorn, P., and Knepper, T. P., 2001, Electrospray ionization mass spectrometric studies on the amphoteric surfactant cocamidopropylbetaine, Journal of Masspectrometry, Vol. 36, pp. 677 - 684 .

16. Belitz H. D. \& Grosch, W. (2002). Food Chemistry, 2nd Edition (Springer-Verlag, Berlin Heidelberg, Germany.

17. Nielsen S. S. (2003). Food Analysis. 3th Ed. Kluwer Academic/Plenum Publisher, New York.

18. Triyono, A. 2010. Mempelajari Pengaruh
Maltodekstrin Dan Susu Skim Terhadap Karakteristik Yoghurt Kacang Hijau. Balai Besar Pengembangan Teknologi Tepat Guna, Teknik Kimia, Universitas Diponegoro Semarang.

19. Thomas, T. D., Pritchard, G. G., (1987), Proteolytic enzymes from dairy starter cultures. Fed. Eur. Microbiol.Soc.Microbiol. Rev. 46:245

20. Rahman, A. (1992). Teknologi Fermentasi. Penerbit Arcan. Jakarta

21. Eitenmiller, W. O., Landen Jr, L Ye, (2008), Vitamin analysis for health and food science, second edition, CRC Press. 